\title{
GREENING THE GREY: IMPLEMENTING GREEN URBAN SOLUTIONS, AS ADAPTATION RESPONSE TO CLIMATE CHANGE, IN A PILOT PROJECT IN LEGAZPI, BASQUE COUNTRY, SPAIN
}

\author{
JON LAURENZ SENOSIAIN ${ }^{1,2}$, JONE BELAUSTEGUIGOITIA ${ }^{1,2} \&$ DANIEL ROEHR $^{3}$ \\ ${ }^{1}$ School of Architecture, The University of the Basque Country, Spain \\ ${ }^{2}$ Lurstudio Koop, Elkarte Txikia, Spain \\ ${ }^{3}$ School of Architecture and Landscape Architecture, The University of British Columbia, Canada
}

\begin{abstract}
This paper focuses on the implementation of green urban infrastructure solutions (GUIS) in an urban pilot project in Legazpi, Gipuzkoa (Spain). It shows the environmental benefits derived from an overall GUIS project, in terms of climate change adaptation, such as ameliorating stormwater runoff, reducing urban hot spots and improving urban air and water quality. The design process followed in this project started with a community engagement with the residents of Legazpi. A series of international case studies of GUIS were presented. The conclusions of the community engagement informed the final design and construction project. A selection of GUIS were implemented including permeable paving with high albedo finishing materials; bio-retention areas; stormwater retention tanks; and a vegetated pergola. During the design phase, the contribution of the applied GUIS to climate change adaptation was analyzed. It shows that proposed GUIS contribute to reduce the runoff by $25 \%$, the urban temperatures by up to $20^{\circ} \mathrm{C}$, and sequester the $7 \%$ of the $\mathrm{CO}_{2}$ emissions from the site. The paper includes lessons learned and the barriers identified when implementing these GUIS. It demonstrates that implementing GUIS in an urban renovation project in Legazpi, are effective to mitigate climate change consequences. Larger projects and more experience are needed in both the construction sector and the technical professionals, to move from pilot projects to common practice. Keywords: green urban infrastructure, climate change adaptation urban solutions, sustainable urban drainage system, urban greenery, nature based urban solutions, stormwater management, green streets, low impact development, environmental benefits, water sensitive urban solutions.
\end{abstract}

\section{INTRODUCTION}

This paper implements GUIS in a pilot project and analyses what a green urban intervention contributes to climate change adaptation. The International Paris Agreement in 2015 [1], achieved an international compromise of main countries around the world to strengthen the global response to the risks of climate change. In addition, the IPCC Climate Change Report of October 2018 [2], called for urgent actions in order to limit climate change impacts. This paper analyses how GUIS contribute to reduce the risks of climate change and suggests more ambitious and rigorous green urban interventions should be carried out.

Several initial questions were asked: do these GUIS reduce the impacts of climate change, do they meet expectations in terms of climate change adaptation, under what terms are they met? This paper provides some clarity on the suitability of GUIS. It analyses the degree to which these environmental benefits are achieved by implementing GUIS into an urban project in a small Basque municipality, Legazpi, of less than 8,500 inhabitants. The project is part of a LIFE European Project (Good Local Adapt) [3], which includes public engagement in order to understand the needs of the residents and to identify the GUIS that better respond not only to climate change but also to citizen's needs. The engagement process included the selection of GUIS implemented in the project: permeable paving and 
high albedo finishing materials; bio-retention areas; stormwater retention tanks; and a vegetated pergola. The paper includes the analysis of the contribution of these GUIS to ameliorate the impact of climate change in three main areas: The reduction of runoff (by $25 \%$ ), and consequently the reduction in the risks of floods. The reduction of urban heat island, by lowering the urban surface temperature (by up to $20^{\circ} \mathrm{C}$ ). The contribution to air and water quality by $\mathrm{CO}_{2}$ sequestration through the new greenery (sequestering the $7 \%$ of the $\mathrm{CO}_{2}$ emissions attributable to that area). This paper includes the lessons learned from the implementation of GUIS, and helps to inspire other urban designers to follow a more rigorous design process. It also highlights the barriers found during the project and it concludes advocating for larger and urgent GUIS projects, in order to meet the compromises of the Paris Agreement.

\section{PILOT PROJECT DESIGN PROCESS}

The design process included the following stages:

1. Community Engagement - a two-part community engagement process, that identified the needs of the residents and assessed the GUIS to be incorporated into Stage 2 (design).

2. Design - integrated the GUIS selected through the engagement process. These included permeable paving and high albedo finishing materials; bio-retention areas; stormwater retention tanks; and a vegetated pergola. These GUIS were installed into the project site.

3. Analysis - the contribution of such GUIS to climate change adaptation, in terms of reducing the stormwater runoff, ameliorating urban heat island effect and contributing to water \& air quality were analysed during design.

4. Construction - the selected GUIS were implemented and built on the specific site of Legazpi.

5. Review - includes the lessons learned, conclusions and discussion.

\section{COMMUNITY ENGAGEMENT}

The community engagement was divided in two major sessions: S0 and S1. The first one, focused on more general concepts of climate change and adaptation solutions. It was held in four neighbourhoods of Legazpi (San Inazio, San Marin, Arantzazu and San Jose). The second session, focused specifically on the site and the solutions to be implemented, was held in the San Inazio neighbourhood. The two main sessions were divided in two subsessions, the first one (S01) focused on analysis; and the second (S02) focused on the opportunities to improve their neighbourhoods. The first session S0 was undertaken utilizing both face-to-face participation and digital participation (through an on-line platform). The objectives of the engagement were to raise awareness regarding the consequences of climate change at a local level, to identify the needs and opportunities of both traditional and innovative adaptation solutions, and to compare and prioritize with the citizens the specific GUIS solutions being proposed for use at a local level. In the first sessions S01, residents identified their needs on a neighbourhood map. In session S02 a set of GUIS around the world were provided and participants prioritized their opportunities in a map (Fig. 5) or voting (raising hands). The digital consultation method were statements according to which participants had to express a degree of agreement (from total agreement to total disagreement). In the first sub-session S1.1, of session 2, the needs for the specific site were discussed, and in sub-session 1.2 participants selected their GUIS preferences to be implemented on the specific site. Fig. 1 shows the participation diagram followed during the first main engagement sessions (S01, and S02). Fig. 2 shows some of the sessions. 


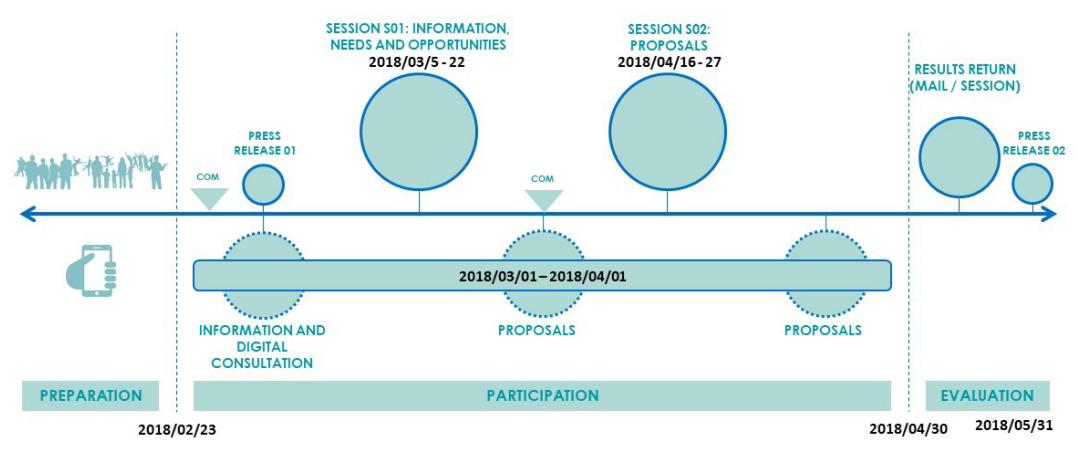

Figure 1: Participation diagram with the three phases: preparation, participation and evaluation. Above the line, is the face-to-face participation main milestones. Below the line, are the main digital participation milestones. (Source: Image by the authors.)
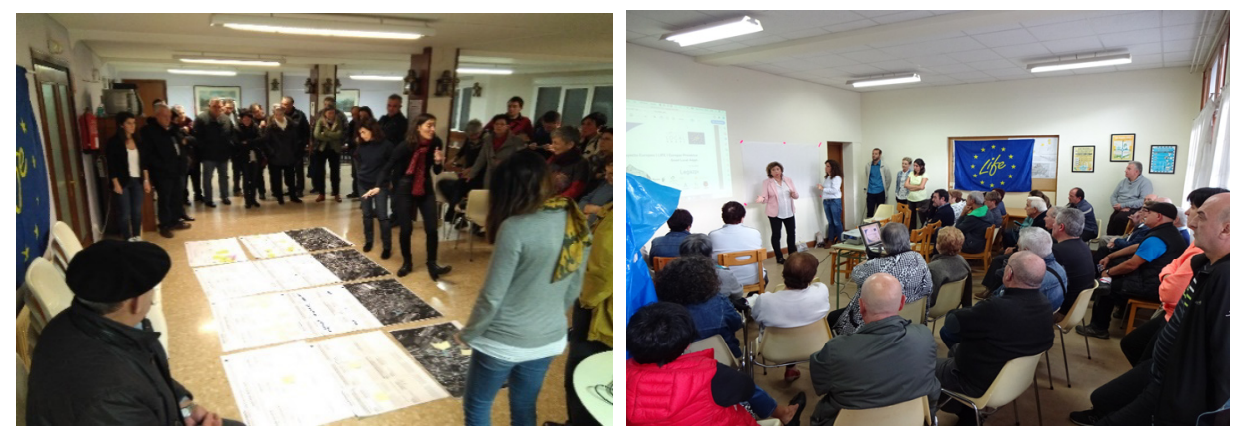

Figure 2: The participation process (left S0.1; right S1.2). (Source: Images by the authors.)

\subsection{Participation indicators}

\subsubsection{Participation by number and means}

Overall, 168 people participated in all four sessions (Fig. 3). The majority of participation was face-to-face, while digital, and online consultation, had a significantly lower participation rate.

\begin{tabular}{|lccccccc|}
\multicolumn{1}{c}{ FOUR SESSIONS } & $\begin{array}{c}\text { Session } 0 \\
\text { SO.1 }\end{array}$ & $\begin{array}{c}\text { Session 0 } \\
\text { SO.2 }\end{array}$ & $\begin{array}{c}\text { Session } 1 \\
\text { S S1.1 }\end{array}$ & $\begin{array}{c}\text { Session 1 } \\
\text { S1.2 }\end{array}$ & $\begin{array}{c}\text { TOTAL } \\
\text { FACE-TO-FACE }\end{array}$ & $\begin{array}{c}\text { TOTAL } \\
\text { DIGITAL }\end{array}$ & TOTAL \\
Number of participants & 39 & 47 & 48 & 29 & $\mathbf{1 6 3}$ & $\mathbf{5}(\mathrm{SO})$ & $\mathbf{1 6 8}$ \\
Women (\%) & $47 \%$ & $55 \%$ & $52 \%$ & $45 \%$ & $\mathbf{5 0 \%}$ & $\mathbf{8 0 \%}$ & $\mathbf{5 0 \%}$ \\
Men (\%) & $53 \%$ & $45 \%$ & $48 \%$ & $55 \%$ & $\mathbf{5 0 \%}$ & $\mathbf{2 0 \%}$ & $\mathbf{5 0 \%}$ \\
\hline
\end{tabular}

Figure 3: Number of participants by gender. (Source: Image by the authors.)

\subsubsection{Participation by gender}

From a gender perspective, participation in all four sessions has been quite balanced, with $50.01 \%$ women and $49.99 \%$ men participating. 


\subsubsection{Participation by age}

Average age of participants was over 65 (by visual observation in face-to-face sessions), while in digital participation the average age was between 30 and 45 years old.

3.1.4 Participation by stakeholder group and residential origin

In all four sessions, participants were mostly local residents.

\subsection{Results of the community engagement}

3.2.1 Citizens' prioritized climatic risks in the demonstrative neighbourhoods

In session S01 participants prioritized the climatic risks as: floods, followed by droughts and heat waves. They identified on a map where these risks are more pronounced in both public space and buildings.

\subsubsection{Citizens' input on needs and opportunities for adaptation in public space}

The needs and opportunities for climate change adaptation design solutions in public space according to participants in the different sessions are summarized below, in order of priority (Figs 4 and 5). The results are summarized in Fig. 6.

\subsection{Evaluation and conclusions}

\subsubsection{Participants' evaluation}

Participants had the opportunity to evaluate the engagement sessions. Ten evaluations were completed and overall, the engagement was well received. Out of the 10 evaluation sheets gathered from the sessions, $60 \%$ thought the sessions were an informative way to approach climate change design solutions, and that they would recommend this type of community engagement for similar plans and projects. Additionally, $100 \%$ of participants agreed facilitators communicated clearly and were easily understood, and that was communicated in a respectful way between the participants. They also made a few recommendations on how to improve the sessions (Fig. 7).

\subsubsection{Conclusions on the overall community engagement}

The community engagement achieved the expectations as the three initial objectives were met. This was mainly due to the active engagement of those who participated and defined specific proposals which were considered by the city and the design team for implementation in the subsequent design project.

\section{NEEDS AND OPPORTUNITIES FOR ADAPTATION IN PUBLIC SPACE IN LEGAZPI}

(from higher (1) to lower (4) priority)

1. Need to increase shade with more natural solutions (trees and vegetation); but maintaining current parking lot numbers.

2. Need to decrease impervious surfaces and create SUDS (Sustainable Urban Drainage Systems), in order to reduce current humidity affecting dwellings adjacent to streets.

3. Opportunity to introduce community gardens (was not interested)

4. Need to increase shadow through hard urban elements (was not interested)

Figure 4: Needs and opportunities for adaptation in public space. (Source: Image by the authors.) 

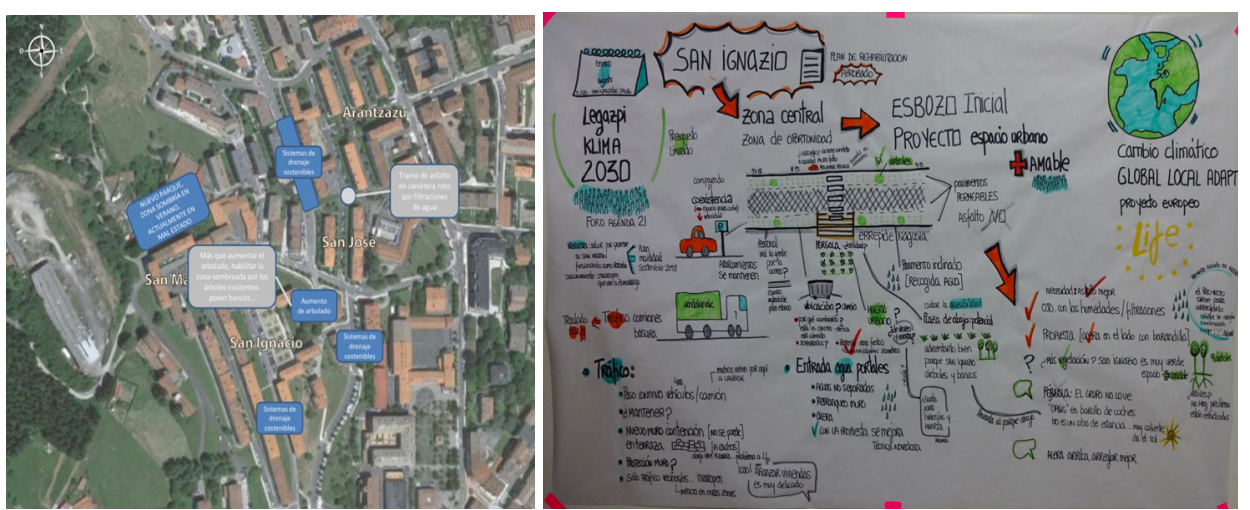

Figure 5: Participants identified their needs and opportunities in their neighbourhoods' maps (S0). A diagram summarizes the outcome of session S1.1. (Source: Images by the authors.)

\begin{tabular}{|c|c|c|c|c|}
\hline & Session S0.1 & Session S0.2 & Session S1.1 & Session S1.2 \\
\hline $\begin{array}{l}\text { SUMMARY OF } \\
\text { RESULTS }\end{array}$ & $\begin{array}{l}\text { - Needs Identified } \\
\text { - Climatic risks } \\
\text { prioritized }\end{array}$ & $\begin{array}{l}\text { - GUIS examples } \\
\text { - Opportunities } \\
\text { Identified on } \\
\text { map }\end{array}$ & $\begin{array}{l}\text { - Specific Needs } \\
\text { \& Opportunities } \\
\text { for the site } \\
\text { identified }\end{array}$ & $\begin{array}{l}\text { - GUIS selected } \\
\text { for the site } \\
\text { - Consensus } \\
\text { achieved }\end{array}$ \\
\hline
\end{tabular}

Figure 6: Summary of the results from the engagement sessions. (Source: Image by the authors.)

\section{This session has been useful. \\ 2. Facilitators have communicated in a clear and easily understandable way.}

\section{Participants have talked with respect.}

4. I would recommend this type of processes.

\begin{tabular}{|c|c|c|}
\hline Agree & In between & Disagree \\
\hline $60 \%(6)$ & $40 \%(4)$ & $0 \%$ \\
\hline $100 \%(10)$ & $0 \%$ & $0 \%$ \\
\hline $100 \%(10)$ & $0 \%$ & $0 \%$ \\
\hline $60 \%(6)$ & $40 \%(4)$ & $0 \%$ \\
\hline
\end{tabular}

Figure 7: Participants' evaluation of the engagement. (Source: Image by the authors.)

At the same time, participants had the opportunity to see case studies from other parts of Europe and their potential replicability in their municipalities. Surveys showed participants' awareness for climate change and its consequences was raised, and they also valued the engagement process.

The involvement of municipal technicians and political representatives as part of the stakeholders should also be highlighted. This is important to promote the later application of these measures in pilot projects, as future project actions, such as the design project defined in the following section. 


\section{IMPLEMENTATION OF GREEN URBAN INFRASTRUCTURE SOLUTIONS IN THE PILOT PROJECT OF LEGAZPI, BASQUE COUNTRY}

Based on the input from the community engagement, the design team implemented the identified GUIS in the design project including permeable paving with high albedo finishing materials; bio-retention areas; stormwater retention tanks; and a vegetated canopy. A soil permeability study was included in the project which was key to reconsider preliminary design of GUIS. This study showed that the soil characteristic was impermeable (mainly clay), which changed the solution of directly infiltrating rainwater into the soil, to including a stormwater tank. Thus, the rainwater was guided, collected and retained into the tank to reuse it for irrigation or cleaning of streets. The design included a new $1.5 \mathrm{~m}$ wide pedestrian area, 9 new trees, and respected existing parking lot numbers. This last aspect was indicated as mandatory by residents during the engagement process. The scheme of the proposal is summarized in the following Fig. 8.

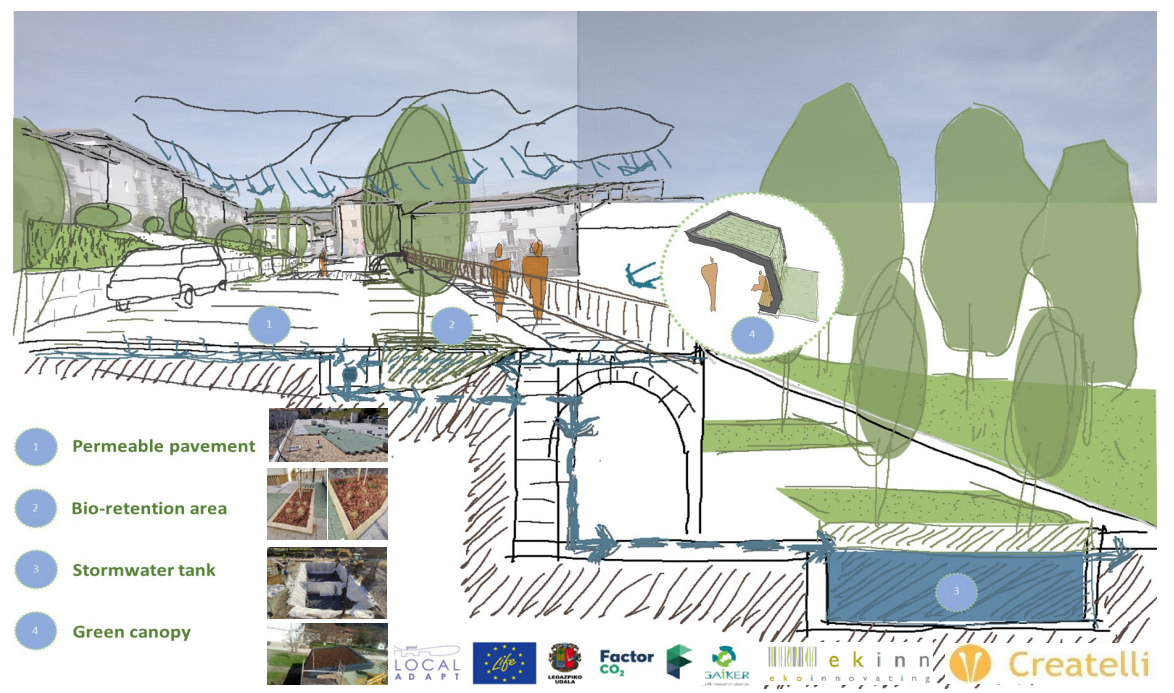

Figure 8: Scheme of the main GUIS implemented in the project. (Source: Image by the authors.)

\subsection{Permeable pavement and high albedo finishing materials}

The design proposed a new permeable pavement to avoid current generation of puddles (indicated in the community engagement as a problem) and with high albedo materials to reduce the heat island effect. Moreover, the new pavement, made of porous concrete, is mostly placed on the existing asphalt, due to the impermeability of the existing soil, and the rainwater is guided to the stormwater tank (Fig. 9).

\subsection{Bio-retention areas}

The project includes 9 new bio-retention areas which integrate 9 new trees ( 5 birches and 4 liquidambars), combined with esparto grass and gramineous grass. Again, due to the impermeability of the terrain, the overflow rainwater of these bio-retention areas is connected to the stormwater tank (Fig. 10). 

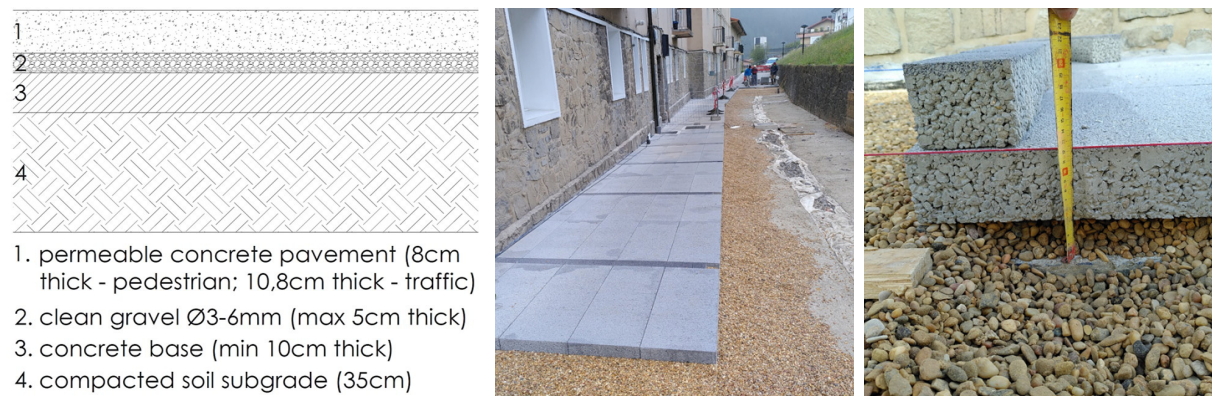

Figure 9: Permeable pavement construction system during the work. (Source Images by the authors.)
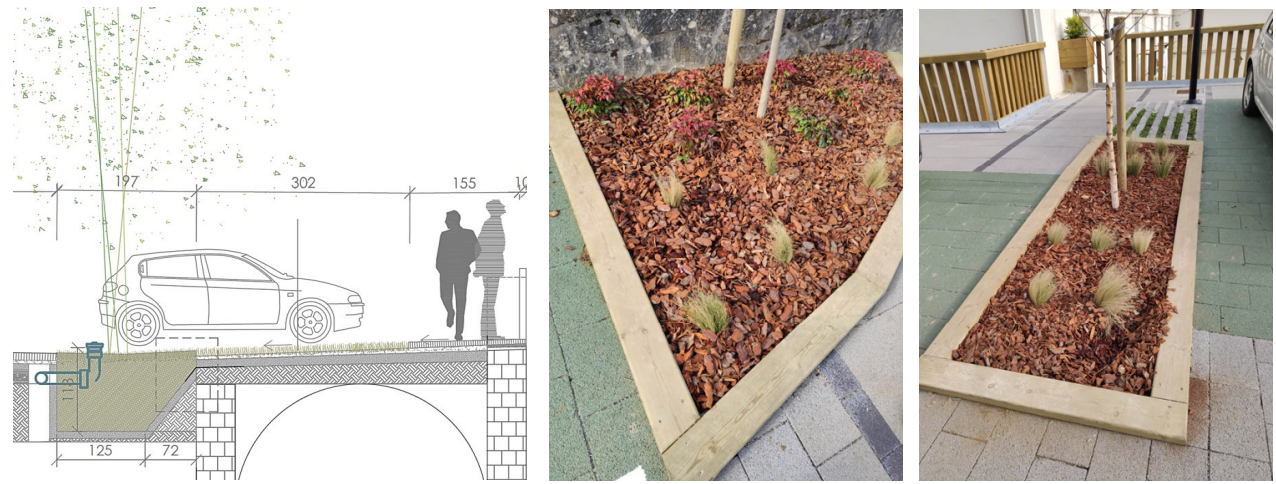

Figure 10: Bio-retention areas and trees. (Source: Drawing by the authors and images by Ruben Cañadas, municipal architect.)

\subsection{Stormwater tank}

Due to the impermeable ground, rainwater is collected and guided to a stormwater tank made out of reinforced polyurethane cells, covered by EPDM water proof membranes and vegetated soil. The volume of the tank is $41.85 \mathrm{~m}^{3}$, calculated to retain a medium rainwater event of $25 \mathrm{l} / \mathrm{m}^{2}$ (Fig. 11).

\subsection{Vegetated canopy}

The project includes a vegetated pergola, made out of wood, which integrates a new moss roof and wall system, which is tested in the project. The waterproofing of the canopy is by a bituminous roof proofing membrane, a biodegradable coconut layer and the moss plants and substrate (Fig. 12).

\section{CONTRIBUTION OF GREEN URBAN SOLUTIONS TO CLIMATE CHANGE ADAPTATION}

The paper also analysed the contribution of proposed GUIS to ameliorate the impact of climate change, in terms of the reduction of runoff, the reduction of urban heat island, and the contribution to air and water quality. 

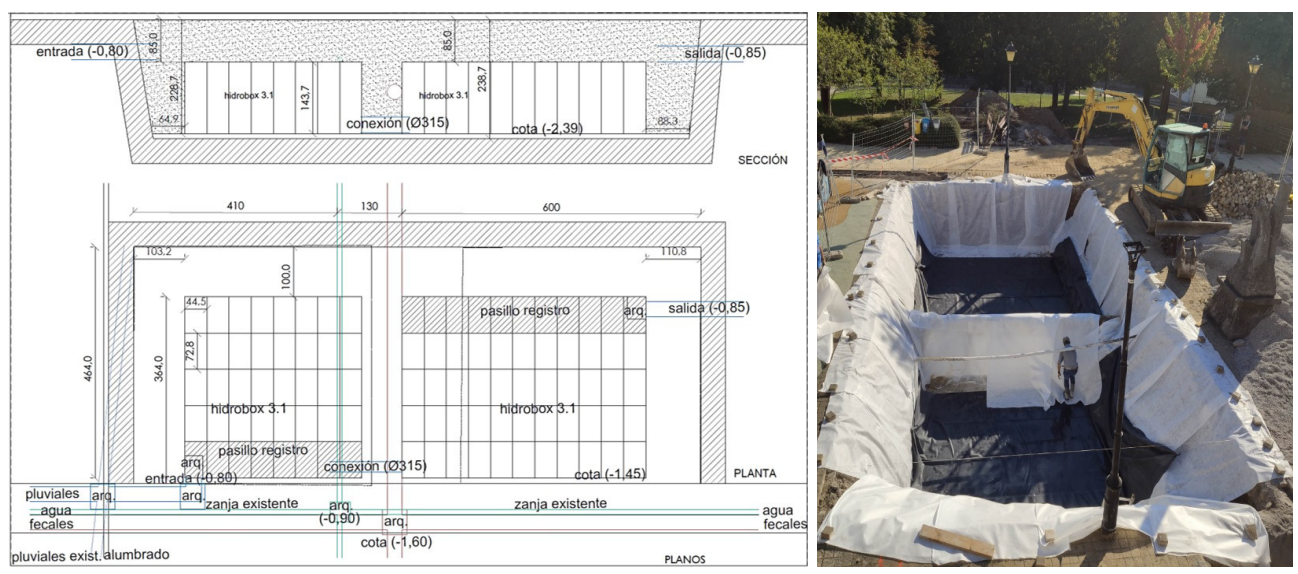

Figure 11: Construction process of the stormwater tank. (Source: Drawing by the authors and image by Marc Rips, Ekinn.)

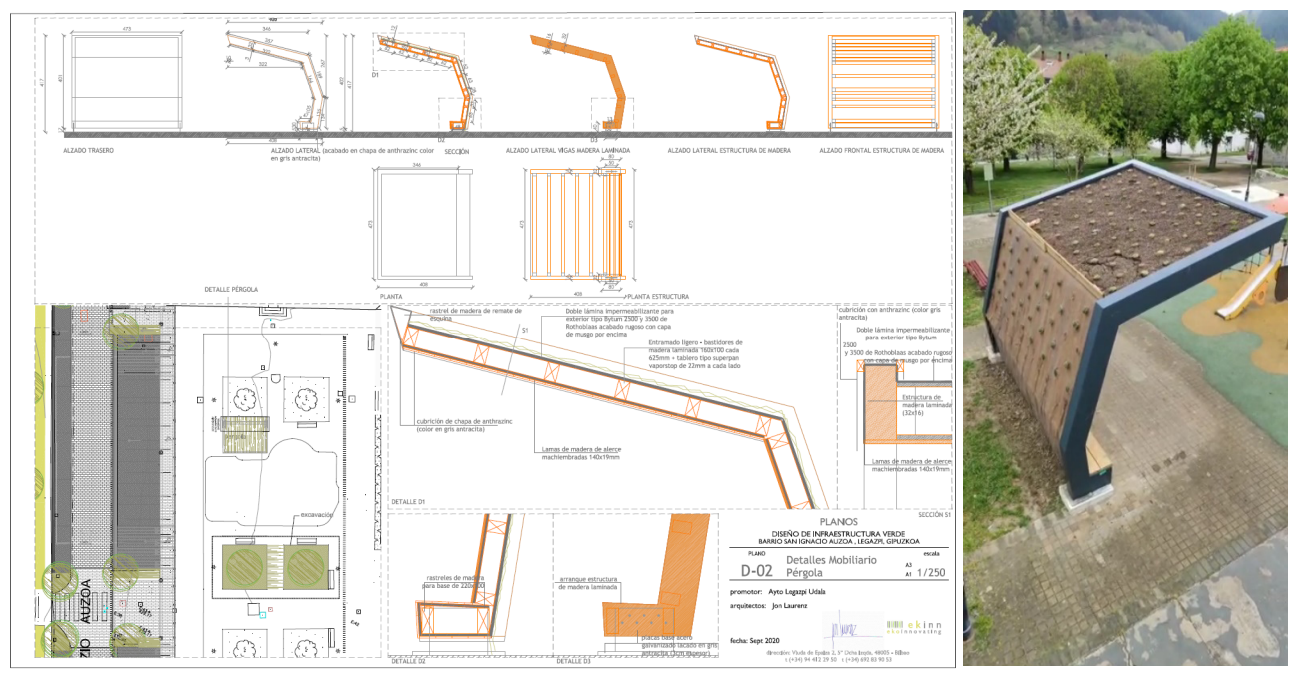

Figure 12: Vegetated canopy. (Source: Drawing by the authors and images by Ruben Cañadas.)

\subsection{Contribution to the reduction of runoff from the site}

GUIS contribute to retaining and collecting rainwater runoff. Green roofs retain between $20-30 \%$ rainwater [4]. Green walls retain 50-75\% and can reach $100 \%$ [5]. By implementing green roofs, green walls and green streets solutions stormwater runoff can be reduced by $13 \%$ [6] A global green urban infrastructure strategy can retain $90 \%$ of a city's runoff [7].

The pilot project proposed $23.3 \mathrm{~m}^{2}$ of vegetated roof (in the vegetated pergola), $26 \mathrm{~m}^{2}$ of bio-retention areas, and a $41.85 \mathrm{~m}^{3}$ rainwater tank. Considering these GUIS areas and based 
on mentioned research studies, this paper estimates that an average of $25 \%$ runoff reduction was achieved.

\subsection{Contribution to the reduction of urban heat island}

The contribution of GUIS to reduce the urban heat island effect is based on relevant publications. For example, in urban parks, for every $100 \mathrm{~m}^{2}$ of vegetation, air temperature is reduced by $1{ }^{\circ} \mathrm{C}$, and that by increasing the ratio of green area to built area by $10 \%$ a $0.8^{\circ} \mathrm{C}$ reduction is achieved (Dimoudi and Nicolopoulou [8]). Similarly, Central Park in New York reduces the nearby temperature by $2-5^{\circ} \mathrm{C}$ (Rosenzweig et al. [9]), and Shinjuku Gyoen Park in Tokyo reduces the urban heat island effect by $2{ }^{\circ} \mathrm{C}$ and decreases the temperature in adjacent areas within the range of 80-90 m from the boundary (Honjo et al. [10]). Vegetated courtyards reduce air temperature approximately $4-5^{\circ} \mathrm{C}$ (Reynolds [11]), and vegetated roofs reduce air temperature between $0.5-2^{\circ} \mathrm{C}$ (The City of Toronto and Ryerson University [12]). The following Fig. 13 also shows this capacity of greenery to reduce urban surfaces temperature (up to $20^{\circ} \mathrm{C}$ ).
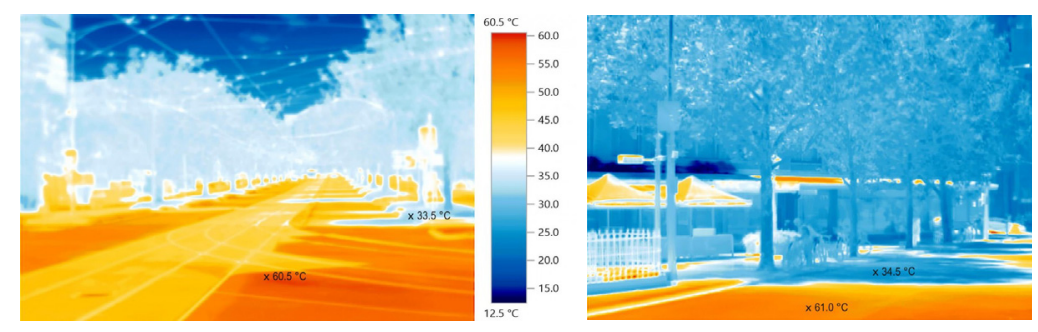

Figure 13: Urban surface temperatures under the sun or under the shadow of trees [13].

This contribution of the vegetation to reduce the urban heat island effect has a direct influence on the reduction of $\mathrm{CO}_{2}$ emissions, since it reduces the energy demand of buildings as explained below.

\subsection{Contribution to the reduction of $\mathrm{CO}_{2}$ emissions}

The contribution of urban greenery to $\mathrm{CO}_{2}$ emissions, due to the reduction of the energy demand of buildings, can be estimated to be around 10-15\% [14]-[18] However, in the Legazpi's pilot project, proposed urban greenery doesn't significantly affect to the nearby buildings. Thus, this paper estimates the reduction of $\mathrm{CO}_{2}$ emissions through the capacity of the greenery to sequester $\mathrm{CO}_{2}$. Based on the data from Schaefer et al. [19]; it estimates that grassy plants from the bio-retention areas and vegetated canopy would trap $281.63 \mathrm{~kg}$ of $\mathrm{CO}_{2} /$ per year; and climber plants from the canopy would trap around $153.1 \mathrm{~kg}$ of $\mathrm{CO}_{2} / \mathrm{per}$ year. Additionally, according to McPherson et al. [20] the proposed 9 trees, with a diameter less than $7 \mathrm{~cm}$, would trap around $0.18 \mathrm{~kg}$ of $\mathrm{CO}_{2} /$ year.

Therefore, the combined contribution of the proposed GUIS to the sequestration of $\mathrm{CO}_{2}$ is $434.89 \mathrm{~kg}$ of $\mathrm{CO}_{2} /$ per year is shown in the following Fig. 14.

Considering that the $\mathrm{CO}_{2}$ emissions of Legazpi is around $154,241 \mathrm{tCO}_{2} \mathrm{e}$ [21], for a municipality of $42.17 \mathrm{~km}^{2}$ [22]. A quick calculation suggests that Legazpi emits 3,657.6 $\mathrm{tCO}_{2} \mathrm{e} / \mathrm{km}^{2}$; which is $3.66 \mathrm{kgCO}_{2} \mathrm{e} / \mathrm{m}^{2}$. The pilot area of $1,675 \mathrm{~m}^{2}$, would mean it 


\begin{tabular}{|c|c|c|c|c|}
\hline \multicolumn{5}{|c|}{ ESTIMATION OF THE CO2 SEQUESTRATION IN THE LEGAZPI PROJECT } \\
\hline \multirow{6}{*}{ LEGAZPI } & & surface $(\mathrm{m} 2)$ & $\begin{array}{c}\text { sequestration } \\
(\mathrm{kg} / \mathrm{m} 2)[18]\end{array}$ & $\begin{array}{c}\mathrm{CO}_{2} \text { sequestration } \\
(\mathrm{kg} / \text { year })\end{array}$ \\
\hline & Grassy plants & 64.3 & 4.38 & 281.634 \\
\hline & Cilmbers & 23.3 & 6.57 & 153.081 \\
\hline & & number (ud) & $\begin{array}{l}\text { sequestration } \\
\text { (kg/ud.year) [19] }\end{array}$ & \\
\hline & Young trees & 9 & 0.02 & 0.18 \\
\hline & TOTAL & & & 434.895 \\
\hline
\end{tabular}

Figure 14: $\mathrm{CO}_{2}$ sequestration by the GUIS of the project. (Source: Image by the authors.)

corresponds a $6,126.48 \mathrm{CO}_{2} \mathrm{e}$ emissions to that area. Since the proposed GUIS contribute to sequester $434.91 \mathrm{~kg}$ of $\mathrm{CO}_{2}$, which means a $7 \%$ of the $\mathrm{CO}_{2}$ emissions attributable to the site area. However, this pilot project only increased the urban greenery by $4 \%$. Thus, these results show the limitations of urban greenery to significantly reduce $\mathrm{CO}_{2}$ emissions by sequestering it.

The overall results of this section shows that GUIS are effective to reduce the urban heat island and stormwater runoff of a specific area (Fig. 15). They can also achieve more modest results to reduce $\mathrm{CO}_{2}$ emissions. It concludes that more ambitious urban greening interventions should be addressed in order to achieve better climate change adaptation results.

\section{CONTRIBUTION OF PILOT PROJECT'S GUIS TO CLIMATE CHANGE ADAPTATION}

REDUCTION OF RUNOFF

REDUCTION OF URBAN HEAT ISLAND

REDUCTION OF $\mathrm{CO}_{2}$ EMISSIONS
$25 \%$

UP TO $20 \circ \mathrm{C}$

$7 \%$

Figure 15: Summary of the contribution of GUIS to CC adaptation. (Source: Image by the authors.)

\section{CONCLUSION AND DISCUSSION}

This paper highlights the potential of GUIS as an effective climate change adaptation solution. It implements GUIS in a specific pilot project in Legazpi, Basque Country. It outlines the design process highlighting the community engagement to both select the GUIS applicable to the site and to raise awareness regarding the consequences of climate change at a local level. A series of findings on how these green urban interventions contribute to climate change adaptation is provided, in terms of reducing the urban stormwater runoff and the risk of floods; as well as the influence on the urban heat island effect and $\mathrm{CO}_{2}$ sequestration.

Results demonstrate that by the proposed GUIS on the site (Legazpi), 25\% of runoff could be reduced; urban surfaces temperatures reduced by $2{ }^{\circ} \mathrm{C}$ and up to $20^{\circ} \mathrm{C}$; and $7 \%$ of the $\mathrm{CO}_{2}$ emission sequestered. This pilot project shows that GUIS are effective for climate change adaptation. Specially to reduce runoff and urban heat island effect, and in a more modest way to reduce $\mathrm{CO}_{2}$ emissions. 
This implementation of GUIS in the pilot project of Legazpi, provided valuable lessons for future designs. For instance, the convenience of including elements that allow more space for the roots of trees in the bio-retention areas; as well as the recommendation to include a drain pump for the stormwater tank, or an irrigation system for the vegetated pergola. Another valuable aspect was the community engagement during the design phase. The engagement process provided a better understanding of the needs of the citizens in the project, and reflected priorities of the residents in the GUIS implemented in the project. The design process is useful to get community support for an urban project.

The project identifies the main barriers encountered when implementing this type of GUIS, and it shows that there are still many challenges which are summarized below:

1. The little experience in this type of projects of all agents involved in the project: the design team, the construction company, and the municipal technicians.

2. The skepticism and distrust towards new urban solutions (GUIS); which reflect the need to continue working and promoting them to increase the experiences of all the agents involved. This would generate more confidence in GUIS.

The authors suggest larger green urban projects should be promoted in order to meet the commitments made in the International Paris Agreement. This effort should be accompanied by training courses on green solutions for all the agents involved in these types of projects from designers, developers, to builders, planners, municipal technicians, and decision makers.

The paper emphasizes that this type of green urban infrastructure design process is effective for adapting to climate change, creating consensus within the community and developing a more resilient urban space. It advocates to move from pilot projects to common practice. Finally, it urges to promote this type of GUIS in larger scale projects in order to increase the experience and confidence in GUIS.

\section{ACKNOWLEDGEMENT}

The authors would like to acknowledge and express our gratitude to Feng $\mathrm{Wu}$ and Jericho Bankston for their invaluable support in applying the UBC-Greenskinslab LID Calculator Application to the pilot project of Legazpi.

\section{REFERENCES}

[1] The Paris Agreement. https://unfccc.int/process-and-meetings/the-paris-agreement/ the-paris-agreement. Accessed on: 1 May 2021.

[2] IPCC Press Release, 8 Oct. 2018. https://www.ipcc.ch/site/assets/uploads/2018/11/ pr_181008_P48_spm_en.pdf. Accessed on: 1 May 2021.

[3] LIFE-Good Local Adapt European Project. https://goodlocaladapt.com/. Accessed on: 1 May 2021.

[4] Roehr, D. \& Fassman-Beck, E., Living Roofs in Integrated Urban Water Systems, Routledge, Taylor \& Francis Group: London, 2015.

[5] Ostendorf, M., Retzlaff, W., Thompson, K., Woolbright, M., Morgan, S. \& Celik, S., Stormwater runoff from green retaining wall systems. Cities Alive! 9th Annual Green Roof and Wall Conference, Philadelphia, pp. 1-15, 2011.

[6] Roehr, D., Laurenz, J. \& Kong, Y., Green envelopes: Contribution of green roofs, green facades, and green streets to reducing stormwater runoff, $\mathrm{CO}_{2}$ emissions, and energy demand in cities. International Low Impact Development Conference, pp. 1$8,2008$. 
[7] The City of Vancouver, Rain City Strategy. https://vancouver.ca/home-propertydevelopment/green-infrastructure-documents-and-policies.aspx. Accessed on: 24 Apr. 2021.

[8] Dimoudi, A. \& Nicolopoulou, M., Vegetation in urban environment: Microclimatic analysis and benefits. Energy and Buildings, 35, pp. 69-76, 2003.

[9] Rosenzweig, C., Solecki, W.D. \& Slosberg, R.B., New York city's heat island with urban forestry, living roofs and light surfaces. New York State Energy Research and Development Authority, NY, 2006.

[10] Honjo, T. et al., Observation of thermal effect of Shinjuku Gyoen Park. AMS 4th Symposium on the Urban Environment, Norfolk, VA, pp. 84-85, 2002.

[11] Reynolds, J.S., Courtyards: Aesthetic, Social and Thermal Delight, John Wiley: New York, 2002.

[12] The City of Toronto and Ryerson University, Report on the Environmental Benefits and Costs of Green Roof Technology for the City of Toronto, 2005.

https://web.toronto.ca/wp-content/uploads/2017/08/8f39-Report-on-the-

Environmental-Benefits-and-Costs-of-Green-Roof-Technology-for-the-City-of-

Toronto-Full-Report.pdf. Accessed on: 5 Jul. 2019.

[13] The City of Melbourne. https://e2designlab.com.au/blog/i_2017-11-17-city-coolingmitigation-of-the-urban-heat-island-uhi-effect. Accessed on: 30 Apr. 2021.

[14] Liu, K. \& Baskaran, B., Thermal performance of green roofs through field evaluation. North American Green Roof Infrastructure Conference, 2003.

[15] Hoyano, A., Climatological uses of plants for solar control and the effects on the thermal environment of a building. Energy and Buildings, 11(1-3), pp. 181-199, 1988.

[16] Holm, D., Thermal improvement by means of leaf cover on external walls: A simulation model. Energy and Buildings, 14, pp. 19-30, 1989.

[17] McPherson, E.G. et al., Chicago's evolving urban forest: Initial report of the Chicago urban forest climate project. North-Eastern Forest Experiment Station, Radnor, Pennsylvania, pp. 40-41, 1993.

[18] Laurenz, J., Natural envelope: The green element as a boundary limit. The 2005 World Sustainable Building Conference, pp. 4653-4660, 2005.

[19] Schaefer, V., Rudd, H. \& Vala, J., Urban Biodiversity, Captus Press: Ontario, 2004.

[20] McPherson, E.G. et al., Chicago's Evolving Urban Forest: Initial Report of the Chicago Urban Forest Climate Project, North-Eastern Forest Experiment Station: Radnor, PA, pp. 40-41, 1993.

[21] The City of Legazpi, Programa Municipal de Lucha contra el Cambio Climático de Legazppi 2008-2014. Legazpi, 2010. https://www.globalcovenantofmayors.org/wpcontent/uploads/13 Oct. 2015.Action-Plan_Legazpi.pdf. Accessed on: 12 May 2021.

[22] Legazpi's Municipal Area. https://www.legazpi.eus/es/85-conoce/181-clima-yentorno. Accessed on: 12 May 2021. 